\title{
VALUE-ADDED TAX IN THE DIGITAL ECONOMY: A FRESH LOOK AT THE SOUTH AFRICAN DISPENSATION*
}

\author{
Ruddy Kabwe \\ LLB LLM \\ Doctoral Student, Department of Mercantile Law \\ University of Pretoria \\ Attorney of the High Court of South Africa \\ SP van Zyl \\ LLB LLM LLD \\ Professor, Department of Mercantile Law \\ University of Pretoria \\ Research Fellow, African Tax Institute, University \\ of Pretoria \\ Visiting Professor, Gujarat National Law \\ University, Gandhinagar, India
}

\section{SUMMARY}

The online purchase of digital goods has the propensity to generate tax liability involving a notable rise in administrative costs for tax authorities. Online transactions involving the supply of digital goods by foreign businesses to South African consumers are subject to Value-Added Tax ("VAT"). Since 2014, the Value-Added Tax Act 89 of 1991 provides for registration and the reverse-charge mechanism as a means to collect VAT on online cross-border trade in digital goods. From 1 April 2019, significant changes to the VAT Act have been implemented regulating VAT on online cross-border trade in digital goods. This article examines these amendments by way of a comparative analysis of similar legislation in Australia and the European Union with the main aim of making recommendations for the adequate and costeffective collection of VAT on online cross-border trade in digital goods.

This article is partly based on Ruddy Kabwe's mini-dissertation entitled "Consumption Tax Collection Models in Online Trade in Digital Goods" submitted in partial fulfilment of an LLM (tax law) at the University of South Africa under supervision of Prof SP van Zyl. 


\section{$1 \quad$ INTRODUCTION}

The growth of the digital economy has seen consumers buy digital goods ${ }^{1}$ such as electronic books (e-books), games and music effortlessly at the click of a button. The online cross-border purchase of digital goods by consumers creates Value-Added Tax (VAT) collection challenges. ${ }^{2}$ The challenges are compounded by an apparent lack of international guidelines on the implementation of VAT collection mechanisms on online cross-border trade in digital goods. ${ }^{3}$

Governments face the unwelcome prospect of losing significant revenue in an era where e-commerce transactions, by nature, create a niche market for the purchase of a large quantity of inexpensive digital goods. ${ }^{4}$ The online purchase of digital goods has the propensity to generate tax liability involving a notable rise in administrative costs for tax authorities. ${ }^{5}$

Until fairly recently, South Africa's tax laws did not match the rise of the digital economy. ${ }^{6}$ In respect of VAT legislation, the advent of the Taxation Laws Amendment Act ${ }^{7}$ has brought about change: electronic services, as defined, ${ }^{8}$ supplied by foreign businesses to South African consumers are now subject to VAT in South Africa. ${ }^{9}$ Since 2014, the Value-Added Tax Act ${ }^{10}$ (VAT Act) provides for registration and the reverse-charge mechanism as a means to collect VAT on online cross-border trade in digital goods. From 1 April 2019, significant changes to the VAT Act have been implemented to regulate VAT on online cross-border trade in digital goods.

1 In this context, "digital goods" is a broad term used to describe any goods that are stored, delivered and used in an intangible electronic format. Digital goods are shipped electronically to the consumer through email or downloaded from the Internet or a similar network. This term must not be confused with the specific definitions that have been adopted in VAT/GST legislation.

2 OECD "Addressing the Tax Challenges of the Digital Economy" (2014) http://www.oecdilibrary.org/docserver/download/2314251e.pdf?expires=1447015283\&id=id \&accname $=$ guest $\&$ checksum $=5748$ F58F355A1981B097C2E1AB83CC5D (accessed 201807-06).

3 Ibid.

4 lbid.

Ibid.

6 De Wet "Tax and the Digital Economy: Value Added Tax" 2015353 Tax Breaks Newsletter 44.

743 of 2014.

8 The Regulations prescribing electronic services for the purpose of the definition of "electronic services" in s 1 of the Value-Added Tax Act define "electronic services" as "any services supplied by means of an electronic agent, electronic communication or the Internet for any consideration, other than- (a) educational services supplied from a place in an export country and regulated by an educational authority in terms of the laws of that export country; or (b) telecommunications services; or (c) services supplied from a place in an export country by a company that is not a resident of the Republic to a company that is a resident of the Republic if-

(i) both those companies form part of the same group of companies; and

(ii) the company that is not a resident of the Republic itself supplies those services exclusively for the purposes of consumption of those services by the company that is a resident of the Republic."

$9 \quad S 7(1)(c)$ read with paragraph $1(b)(v i)$ of the definition of "enterprise" in the Value-Added Tax Act 89 of 1991.

1089 of 1991. 
From the outset, it must be noted that the list of what constitutes "electronic services" for purposes of the VAT Act was very limited and, since the promulgation of the amendment, the list had not been updated to keep up with technological advances and new business models. This created uncertainty among taxpayers and suppliers as to the tax treatment of certain digital goods. On 18 March 2019, the revised Regulations to the VAT Act were published, prescribing what constitutes "electronic services" as contemplated in the VAT Act. The revised Regulations came into effect on 1 April 2019.

In 1998, the Organisation for Economic Cooperation and Development (OECD) adopted the Ottawa Taxation Framework for the development of domestic consumption tax laws to deal with electronic commerce. ${ }^{11}$ In this respect, the OECD recommends that VAT rules must be as neutral and equitable as possible for vendors, the VAT system and laws should be efficient and effective, and must create certainty and fairness in treatment for all taxpayers. ${ }^{12}$ In addition, tax rules must be simple and clear to understand. ${ }^{13}$ This article examines the 2019 amendments by way of a comparative analysis of similar legislation in Australia and the European Union (EU) with the main aim of making recommendations for a simplified and effective VAT regime on online cross-border trade in digital goods in compliance with the Ottawa Taxation Framework.

As the collection of VAT in the case of Business to Consumer (B2C) transactions poses the biggest risk, ${ }^{14}$ the scope of this article is limited to a discussion of VAT on B2C transactions only - that is, the sale of digital goods by foreign suppliers to South African consumers. From the outset, it must be noted that the VAT Act, read together with the Regulations ${ }^{15}$ does not distinguish between Business to Business (B2B) and B2C e-commerce transactions.

\section{VAT ON B2C ONLINE TRANSACTIONS FOR DIGITAL GOODS}

In order to impose VAT on a specific transaction, it is necessary to determine whether that transaction falls within the realm of the VAT Act. In terms of section 7(1) of the VAT Act, VAT is levied on the supply of goods and services by a vendor in the course of furtherance of its enterprise; on the importation of goods into South Africa; and on the supply of imported services into South Africa. ${ }^{16}$

11 OECD Committee on Fiscal Affairs Electronic Commerce: Taxation Framework Conditions (1998) 3 4-6.

12 OECD Committee on Fiscal Affairs Electronic Commerce: Taxation Framework Conditions 3 4-5.

13 lbid.

14 Van der Merwe "VAT and E-Commerce" 200315 South African Mercantile Law Journal 371 373; Steyn "VAT and E-Commerce: Still Looking for Answers?" 201022 SA Merc LJ 230 235. This risk is also explained further in this article.

15 The Regulations prescribing electronic services for the purpose of the definition of "electronic services" in $s 1$ of the VAT Act.

16 S 7(1) of the VAT Act. 
It follows that transactions that fall within the ambit of this provision must be levied with VAT at $15^{17}$ per cent on the value of the supply. ${ }^{18}$ Section $7(2)$ of the VAT Act states that a vendor is responsible for paying VAT when the latter supplies goods and services for the furtherance of its enterprise. In contrast, the recipient of imported services is liable for VAT and must pay VAT to the relevant tax authorities. ${ }^{19}$ The VAT Act does not provide for specific place-of-supply rules. ${ }^{20}$ Instead, the place of supply must be deduced by the reading together of section $7(1)$ (the charging provision), section 14 (the reverse-charge mechanism), and the definitions of "goods", "services", "electronic services", "vendor", and "enterprise" in section 1. For this reason, these concepts are discussed below.

\section{Is the supply of digital goods a supply of "goods" or "services"?}

"Services" are defined in the VAT Act as including "granting, assignment, cession or surrender of any right or the making available of any facility or advantage". ${ }^{21}$ This definition is far-reaching and encompasses all commercial activities that are not defined as a supply of goods for purposes of the VAT Act. ${ }^{22}$ SARS has accepted that digital goods form part of the definition of "services" for purposes of VAT. This is in line with the OECD recommendation. However, as the importation of services relies on the reverse-charge mechanism, ${ }^{23}$ a subcategory of services (electronic services) has been incorporated in the VAT Act to allow for deemed place-of-supply rules in respect of the supply of electronic services. ${ }^{24}$ The VAT Act merely defines "electronic services" as the services prescribed by the Minister of Finance in the Regulations.

Regulation R221 of the South African Government Notice 37489 dated 28 March 2014, with an effective date of 1 June 2014 (the old Regulations), listed the services that are classified as "electronic services" for purposes of the VAT Act. ${ }^{25}$ These include:

The VAT rate increased from 14 to 15 per cent on 1 April 2018.

$S 7(1)$ of the VAT Act.

$S 7(2)$ of the VAT Act.

20 See specifically the concerns raised by the Davis Tax Committee Second Interim Report on Base Erosion and Profit Shifting (BEPS) in South Africa, Summary of DTC Report on Action 1: Address the Challenges of the Digital Economy (2014) 7; Davis Tax Committee Final VAT Report (2018) 68-82.

21 S 1 of the definition of "services" in the VAT Act.

22 Silver and Beneke Deloitte VAT Handbook (2015) 11; Meiring A Critical Evaluation of Proposed Methods to Collect Value-Added Tax on Electronically Supplied Services (MCom dissertation, University of Pretoria) 2013 12; SARS Interpretation Note 70 http://www.sars.gov.za/AllDocs/LegalDoclib/Notes/LAPD-IntR-IN-2013-03\%20\%20IN70\%20Supplies\%20made\%20for\%20no\%20consideration.pdf (accessed 2017-1028).

23 In terms of this mechanism, the recipient importer (customer) of the services must submit a VAT return and account for VAT on the transaction. See s 14 of the VAT Act.

24 S 1 of the definition of "electronic services" in the VAT Act.

25 Silver and Beneke Deloitte VAT Handbook 30; Van der Merwe "Foreign VAT Compliance" Paper presented at the Annual Tax Indaba (11-15 September 2017) 
- educational services where the supplier is not regulated by an educational authority in the country (the services include distanceteaching programmes, educational webcasts, internet-based courses or education programmes and webinars);

- games, including electronic games, interactive games and electronic betting or wagering;

- internet-based auction services;

- $\quad$ the digitised contents of any book or electronic book (e-books);

- audio-visual content (any set of moving visual images or other visible signals) and the right to view such content;

- $\quad$ still images and the right to view such images;

- $\quad$ music, including audio clips, broadcasts not simultaneously broadcast over any conventional network in South Africa, jingles, live-streaming performances, ringtones, songs, sound effects and the right the listener has to listen to any of these items; and

- $\quad$ subscription services to any blog, journal, magazine, newspaper, game, internet-based auction service, periodical, publication, social network service, webcast, webinar, website, web application or web series. ${ }^{26}$

Although the VAT Act does not distinguish between B2B and B2C transactions, advertising and computer programmes or software were excluded from the list because it was perceived that these services are generally consumed in the B2B market. Thus, inadvertently, the application of the definition of "electronic services" differentiates between B2B and B2C transactions. ${ }^{27}$

According to SARS, the definitions of "goods" and "services" are expansive to ensure that all economic transactions are included in the tax base. ${ }^{28}$ However, a closer inspection of the definition of "electronic services" (as it then was) suggests that some services had been excluded. The

http://www.taxindaba.co.za/img/downloads/presentations/1.Foreign\%20VAT\%20Complianc e\%20Suzanne\%20vd\%20Merwe.pdf (accessed 2017-03-29).

26 GN R221 "Electronic Services Regulations" in GG 37489 of 2014-03-28; see also Silver and Beneke Deloitte VAT Handbook 30; Van der Merwe http://www.taxindaba.co.za/img/downloads/presentations/1.Foreign\%20VAT\%20Complianc e\%20Suzanne\%20vd\%20Merwe.pdf.

27 In the case of B2C transactions, the foreign supplier of electronic services must register as a VAT vendor in South Africa where the taxable supplies exceed the R50 000 threshold (the threshold that applied until 31 March 2019). In the case of perceived B2B transactions (the supply of computer software), the recipient importer accounts for VAT in terms of the reverse-charge mechanism.

28 SARS "Note Interpretation 70" (2013) http://www.sars.gov.za/AllDocs/LegalDoclib/Notes/ LAPD-IntR-IN-2013-03\%20-\%20IN70\%20Supplies\%20made\%20for\%20no\%20 consideration.pdf (accessed 2017-10-28) 12. 
definition did not include services like cloud computing, ${ }^{29}$ live video streaming, ${ }^{30}$ applications (apps), ${ }^{31}$ and online advertising services. ${ }^{32}$

This problem may be illustrated by the following example:

Mary, a South African resident, has recently started her own business. Mary is not a VAT vendor. She would like to advertise her products to a potential worldwide customer base. She pays Company X, a French online advertising company, to enable her to advertise her products online. Company $\mathrm{X}$ provides Mary with advertising services. Assume that Company $X$ is carrying on an enterprise in South Africa and is duly registered as a vendor in South Africa because it also supplies digital music to South African customers. As Mary is not a VAT vendor, the transaction is treated as a B2C transaction. In this instance, although Company $X$ is a vendor, there was no obligation on it to account for VAT to SARS on the supply of advertising services because it did not supply "electronic services" as defined to Mary. ${ }^{33}$ Similarly, Mary as an importer of the "electronic services" does not have to account for output tax in terms of the reverse-charge mechanism. This is because the type of services rendered does not constitute a supply of "electronic services" because it was not specifically defined in the Act. Of course, it can be argued that, as the advertising service constitutes "imported services", Mary must account for output VAT in terms of the reverse-charge mechanism. However, as the advertising is rendered worldwide, the place of use and consumption, in terms of the use-andconsumption principle, ${ }^{34}$ cannot be determined with accuracy. Accordingly,

29 According to Goetsch ECommerce in the Cloud (2014) 55, cloud computing is "any service delivered over the Internet". This service includes online photo sharing or web-based email. While it can be argued that cloud computing may fall under any of the "electronic services" so listed, it will be difficult to argue that the storage of data in the cloud against a fee constitutes "electronic services" as defined.

30 It may be argued that live video streaming falls under audio-visual content. However, in the authors' view, audio-visual content as defined in the Regulations refers to the download or viewing of a copy of audio-visual files and it does not include the live streaming of audiovisuals.

31 According to Laudon and Traver E-commerce (2014) 59. An app is software application typically operated on a mobile internet-enabled device. While it may be argued that a mobile app may fall under any of the categories listed, the authors are of the view that app-based navigation services, or app-based chat services, or live streaming falls outside the scope of the definition of "electronic services". Similarly, it can be argued that a mobile app constitutes computer software that is excluded from the definition of "electronic services".

32 Online advertising includes displaying banners, games, classifieds and sponsorships. It has been established above that online advertising is excluded from the definition based on the perception that it is consumed primarily in the B2B market.

33 S 7(1)(a) of the VAT Act read with the definition of "enterprise" in the VAT Act. See also the definition of "electronic services" in the Regulations.

34 In terms of the use-and-consumption principle, the services must be taxed in the jurisdiction where the services are used and consumed. In this example, the use and consumption of the advertising service is where the benefit of the services is reaped. As the advertising service cannot be linked to a specific location, the place of use and consumption cannot be determined with accuracy. Accordingly, it is argued that specific place-of-supply rules are essential to resolve this legal conundrum. For a complete discussion of the use-andconsumption principle, see Van Zyl "Determining the Place of Supply or the Place of Use and Consumption of Imported Services for Value Added Tax Purposes: Some Lessons for South Africa from the European Union" 201325 SA Merc LJ 534-554; Van Zyl "The Placeof-Supply Rules in Value Added Tax: Commissioner of the South African Revenue Services $\checkmark$ De Beers Consolidated Mines Limited" 201325 SA Merc LJ 255-265; Van Zyl "Is the 
in the absence of definitive place-of-supply rules, insofar as the advertising is not used and consumed in the Republic, the transaction can potentially escape VAT in South Africa.

The challenge is compounded when different jurisdictions adopt different terms to refer to digital goods and define them differently. For instance, the EU defines "electronically supplied services" as those services that are "delivered over the [I]nternet or an electronic network and the nature of which renders their supply automated and involving minimal human intervention". ${ }^{35}$ The EU published a list of what it deems to be electronically supplied services. The list includes, but is not limited to, the supply of online advertising services, the supply of digital software and the download of digital films. ${ }^{36}$ These services were not listed in the old Regulations under South African law. An EU foreign supplier of software was thus supplying "electronically supplied services" in the EU but this did not constitute "electronic services" if that foreign supplier supplied digital software to a South African consumer for download. Instead, the supply of software fell under imported services in the VAT Act. It follows that services that were not defined in the old Regulations were subject to VAT liability in terms of section $7(1)(c)$ of the VAT Act. ${ }^{37}$ Accordingly, the recipient of the software had to account for VAT on the value of the software so imported in terms of the reverse-charge mechanism.

Interestingly, electronic services are currently defined in the Norwegian VAT Act as those "services delivered remotely using the [I]nternet; which are obtained through the use of information technology". ${ }^{38}$ An essential part of the definition of electronic services is that the delivery of the services should take place without the involvement of any human element. ${ }^{39}$ While this definition is considered broad, the inclusion of the word "Internet" limits the scope to digital goods delivered via the World Wide Web. Digital goods delivered by any other electronic means or system may escape the VAT net.

It is the authors' view that a lack of international coordination and cooperation regarding a uniform definition for digital goods has resulted in a lot of confusion and uncertainty especially for foreign businesses. The responsibility was left to foreign suppliers to determine how a jurisdiction defines digital goods before transacting with its customers. Accordingly, foreign suppliers must familiarise themselves with the consumption tax legislation in every country of supply to ensure that they are compliant. This

Supply of Services in the Duty-Free Area at an International Airport in South Africa Subject to VAT? Master Currency (Pty) Ltd $v$ Commissioner for the South African Revenue Services" 201426 SA Merc LJ 515-532; Commissioner for SARS v De Beers (503/2011) [2012] ZASCA 103 (1 June 2012); Master Currency v CSARS (155/2012)[2013] ZASCA 17 (20 March 2013).

35 European Commission "Electronically Supplied Services" https://ec.europa.eu/ taxation_customs/individuals/buying-goods-services-online-personal-use/buyingservices/electronically-supplied-services_en (accessed 2017-05-20).

36 European Commission "List of Electronically Supplied Services" http://ec.europa.eu/ taxation_customs/sites/taxation/files/resources/documents/common/buying_online/electroni cally_supplied_services.pdf (accessed 2017-05-20).

37 See discussion on registration of foreign suppliers below.

$38 \quad \mathrm{~S} 1-3$ of the Norwegian VAT Act.

39 The definition of "electronic services" in s 1-3 of the Norwegian VAT Act. 
uncertainty may also cause foreign suppliers to stop making supplies altogether to consumers in jurisdictions with cumbersome consumption tax rules. This has a potentially negative impact on international trade and economic advancement in developing countries.

The extension of the definition of "electronic services" in the new Regulations is intended to allow the legislator to amend the regulations easily, so as to keep the list updated in accordance with new technology without the same parliamentary hassles associated with amending the Act. The Davis Tax Committee specifically recommended that the Regulations be refined in order to provide for a comprehensive understanding and appreciation thereof. 40

With effect from 1 April 2019, the definition of "electronic services" in the Regulations has been amended. The previous list of electronic services was replaced by a much broader definition, similar to that of Norway. ${ }^{41}$ Electronic services are now defined as "[a]ny services supplied by means of an electronic agent, electronic communication or the [I]nternet for any consideration". 42 Specifically excluded from the definition are: educational services supplied from a place in an export country and regulated by an educational authority in terms of the laws of that country; telecommunications services; and certain intra-group supplies. ${ }^{43}$ The old Regulations provided a list of specific services constituting electronically supplied services. The new Regulations provide a wide definition and list those services that do not constitute electronically supplied services. While this wide definition encompasses almost any form of technology in existence or yet to be developed, this may lead to instances of double taxation of the service in the jurisdiction of origin and in South Africa. For example, the simultaneous broadcast of a live concert, which physically takes place in the United Kingdom, in the United Kingdom and in South Africa may be subject to VAT in the United Kingdom and in South Africa if it is viewed in South Africa. Similarly, consulting or professional services physically rendered, used and consumed in a foreign jurisdiction may be subject to foreign consumption tax and VAT in South Africa by virtue of the fact that the advice, report, or opinion is also emailed to a recipient in South Africa. ${ }^{44}$

40 Davis Tax Committee 2014 Second Interim Report on BEPS 7-8; Davis Tax Committee 2018 Final VAT Report 90-92.

41 See s $1-3$ of the Norwegian VAT Act.

42 National Treasury Regulations Prescribing Electronic Services for the Purpose of the Definition of "Electronic Services" in Section 1 of the Value Added Tax Act, 1991 (2018) 3.

43 "Services supplied from a place in an export country by a company that is not a resident of the Republic to a company that is a resident of the Republic if-

(i) both those companies form part of the same group of companies; and

(ii) the company that is not a resident of the Republic itself supplies those services exclusively for the purposes of consumption of those services by the company that is a resident of the Republic." See National Treasury Regulations Prescribing Electronic Services for the Purpose of the Definition of "Electronic Services" in Section 1 of the Value Added Tax Act, 1991 (2018) 3.

44 Of course, this is no different for imported services where advice is physically presented in a foreign jurisdiction but where the benefit of the advice is used and applied in the Republic in the furtherance of an enterprise. For a complete discussion of the application of the useand-consumption principle on foreign supplies services, see Van Zyl 2013 SA Merc LJ 534-554; Van Zyl 2013 SA Merc LJ 255-265; Van Zyl 2014 SA Merc LJ 515-532. 
Accordingly, the amended Regulations exacerbate the interpretation dilemma of the use-and-consumption principle instead of providing clear and definitive place-of-supply rules. Also, it can be argued that the specific exclusion of "telecommunication" equates to an exclusion of any service delivered via a telecommunication network. It is common knowledge that both fixed-line and mobile internet services are delivered via a telecommunication network, and that digital downloads are likely to be delivered via a fixed or mobile internet network. At the time of writing, SARS has tried to remedy this confusion on its FAQ page by explaining that any "digital goods" delivered over a telecommunication network do not fall under the exclusion. ${ }^{45}$ The new all-inclusive definition removes the perceived B2B and B2C distinction that was created by the previous list. This is in line with National Treasury's mandate that the VAT Act does not distinguish between $\mathrm{B} 2 \mathrm{~B}$ and $\mathrm{B} 2 \mathrm{C}$ transactions. However, this is in direct contrast to the OECD recommendations that $\mathrm{B} 2 \mathrm{~B}$ and $\mathrm{B} 2 \mathrm{C}$ transactions must be treated differently. ${ }^{46}$

\section{The importance of place-of-supply rules}

South Africa adopts the destination principle ${ }^{47}$ as a justification to impose VAT. ${ }^{48}$ In terms of this principle, economic activity should be taxed in the jurisdiction where it is used and consumed. ${ }^{49}$ This means that the VAT Act applies to South African residents and to the supply of services to South African residents by foreign suppliers in other jurisdictions. ${ }^{50}$ However, owing to the nature of e-commerce, it is often difficult for tax authorities to establish that a supply of services occurred within the borders of South Africa or that it is consumed in the Republic. Hence, the concept of "supply" has become an important concept for tax authorities. ${ }^{51}$

45 See South African Revenue Service website https://www.sars.gov.za/Legal/LegalPublications/Pages/FAQs.aspx (accessed 2020-01-08).

46 OECD "International VAT/GST Guidelines" (2017) http://dx.doi.org/10.1787/ 9789264271401-en (accessed 2020-01-08).

47 In terms of the destination principle, consumer taxes are levied in the jurisdiction where the supply is made. In the case of the origin principle, consumer taxes are levied in the jurisdiction where the supply originates. Generally, in the case of consumer taxes, the destination principle applies. For the purpose of this article, it is assumed that the destination principle applies. See in general Ebrill, Bodin, Keen and Summers The Modern VAT (2001) 15-23; Bird and Gendron The VAT in Developing and Transitional Countries (2007) 108-138.

48 Van der Merwe 2003 SA Merc LJ 374; Steyn 2010 SA Merc LJ 239; Van Zyl The Collection of Value Added Tax Online Cross-Border Trade in Digital Goods (doctoral thesis, UNISA) 2013343.

49 Basu Global Perspectives on E-Commerce Taxation Law (2007) 288; Cockfield, Hellerstein, Millar and Waerzeggers Taxing Global Digital Commerce (2013) 68; Van der Merwe 2003 SA Merc LJ 374; Steyn 2010 SA Merc LJ 239.

50 Musgrave "Digital Taxes Around the World: What to Know About New Tax Rules" https://quaderno.io/blog/digital-taxes-around-world-know-new-tax-rules/ (accessed 2018-0706); Silver and Beneke Deloitte VAT Handbook 25; Commissioner for SARS v De Beers supra; Master Currency v CSARS supra.

51 Cleartax "Place of Supply Rules" https://cleartax.in/s/place-of-supply-gst (accessed 201807-06). 
Assuming the destination principle applies, it is paramount to establish where the supply takes place, or is consumed, as this determines which jurisdiction will collect the necessary consumption tax. ${ }^{52}$ Where the place of supply cannot be determined, place-of-supply proxies ${ }^{53}$ must be incorporated in the VAT Act. As stated above, the VAT Act, in its current form, does not provide for specific place-of-supply rules/proxies. Instead, the place of supply is determined by the use-and-consumption principle. In the absence of clear place-of-supply proxies, transactions can escape the VAT net. ${ }^{54}$ It follows that having explicit place-of-supply rules, particularly in cases of e-commerce transactions, enables tax authorities to impose VAT on transactions, since the place-of-supply rules will establish which transactions will be deemed to take place in South Africa. 55

Rooi correctly states that if the place of supply is unidentifiable, then it becomes impractical, ineffective and inefficient to implement the relevant legislation. ${ }^{56}$ It is the authors' view that appropriate and express place-ofsupply rules for e-commerce transactions must be included in the VAT Act. The way the place-of-supply rules are deduced by the reading together of the charging provision and the definitions of "electronic services", "vendor", and "enterprise" is confusing for foreign suppliers who are not familiar with the South African legal system. While ignorance is no excuse, the authors believe that the complexity of the structure of the VAT Act contributes directly to non-compliance by foreign suppliers and/or an additional administrative burden on SARS officials having to cope with an influx of queries. To mitigate an influx of queries, on 5 July 2019, SARS launched a Frequently Asked Questions (FAQ) section on its website. ${ }^{57}$ This FAQ is updated regularly. However, the authors must note that the FAQ section on the website is not easy to find, nor is it easy to navigate.

\section{Who must register as a foreign supplier of electronic services in South Africa?}

A vendor is any person who is, or is required to be, registered under the Act. ${ }^{58} \mathrm{~A}$ vendor is required to levy VAT on goods and services supplied in the course or furtherance of that vendor's enterprise. ${ }^{59}$ Generally, a person becomes liable to register as a vendor if the taxable supplies made during that period exceed or are likely to exceed R1 million at the end of a 12 -

\footnotetext{
52 Van der Merwe 2003 SA Merc LJ 374. The term "consumption tax" is used here as a broad term that includes VAT and General Sales Tax (GST) or any derivative thereof.

53 A proxy, for purposes of VAT, is a deemed place of consumption that assists in establishing the jurisdiction of taxation. For example, the recipient's physical address can be used as proxy where an e-book is purchased online but is consumed in multiple jurisdictions.

54 See in general Van Zyl 2013 SA Merc LJ 534-554; Van Zyl 2013 SA Merc LJ 255-265; Van Zyl 2014 SA Merc LJ 515-532.

55 Kruger and Moss-Holdstock "The South African VAT Implications for Foreign Suppliers of Electronic Services" 20145 Business Tax and Company Law Quarterly 1415.

56 Rooi An Evaluation of the Practical Application of the South African VAT Legislation on Electronic Services: A Case Study (MCom mini dissertation North-West University) 201580.

57 SARS https://www.sars.gov.za/Legal/Legal-Publications/Pages/ FAQs.aspx (accessed 2020-01-08).

$58 \mathrm{~S} 1$ of the definition of "vendor" of the VAT Act.

59 S 7(1)(a) of the VAT Act.
} 
month period. 60 In the case of the supply of "electronic services" as defined, the annual registration threshold, from 1 April 2019, is R1 million. ${ }^{61}$ Prior to the amendment, the registration threshold for foreign suppliers of "electronic services" was R50 000.62 This created a differentiation between domestic suppliers of "electronic services" and foreign suppliers of "electronic services". At the time of the first amendments in respect of VAT on ecommerce transactions, domestic suppliers of digital goods ${ }^{63}$ complained to Parliament that foreign suppliers of digital goods had an advantage in that they could make similar supplies free of VAT. ${ }^{64}$ In order to protect the domestic market, Treasury found that a differentiated threshold for foreign and domestic suppliers of "electronic services" was optimal. ${ }^{65}$ However, this resulted in a significant number of registrations of foreign vendors in respect of taxable supplies lower than the R50 000 threshold. ${ }^{66}$ Furthermore, this created an additional and costly administrative burden for SARS. ${ }^{67}$ The threshold amendment removed the differentiation between foreign and local suppliers of "electronic services", and it complies with the principle of neutrality. ${ }^{68}$ In addition, it complies with the OECD Ottawa recommendations that there must not be any significant differences between the taxation of electronic commerce and conventional commerce transactions. ${ }^{69}$

\section{Locating the place of supply: the definition of "enterprise"}

The term "enterprise" is an important concept for purposes of the VAT Act. ${ }^{70}$ An enterprise is defined as:

"In the case of any vendor, any enterprise or activity which is carried on continuously or regularly by any person in the Republic or partly in the Republic and in the course or furtherance of which goods or services are supplied to any other person for a consideration, whether or not for profit, including any enterprise or activity carried on in the form of a commercial, financial, industrial, mining, farming, fishing, municipal or professional concern or any other concern of a continuing nature or in the form of an association or club." 11

$60 \mathrm{~S} 23(1)(a)$ of the VAT Act.

S 23(1A) of the VAT Act, with effect from 1 April 2019.

62 S 23(1A) of the VAT Act, as it applied until 31 March 2019.

63 The authors refer to the term "digital goods" here because the definition of "electronic services" did not exist at the time.

64 Naidoo Taxing Cross-Border Trade in the Digitised Economy, Session 6 OECD Workshop 10-14 June 2019 South African Revenue Service, Megawatt Park.

65 Ibid.

66 Ibid.

67 Ibid.

68 See the concerns raised by the Davis Tax Commission that the VAT registration threshold for foreign suppliers of electronically supplied services does not comply with the principle of neutrality. Davis Tax Committee Second Interim Report on BEPS 13; Davis Tax Committee 2018 Final VAT Report 92-93.

69 OECD Committee on Fiscal Affairs Electronic Commerce: Taxation Framework Conditions 4.

70 SARS Interpretation Note 70.

71 S 1 of the definition of "enterprise" of the VAT Act. 
The definition of enterprise is quite broad. It is the authors' view that the legislator incorporated every possible commercial activity in the definition for the activity to be subject to the VAT Act.

The definition of "enterprise" is not limited to businesses operated in South Africa. A foreign business that regularly supplies services in South Africa will be deemed to be conducting an enterprise in South Africa. ${ }^{72}$ Whether a foreign business conducts its business from inside or outside South Africa is a question of fact. Generally, a foreign business is considered to have a permanent or fixed address in a foreign jurisdiction. The problem occurs when a supplier of services (particularly a foreign supplier of "electronic services") does not have a physical presence anywhere in the world but operates in the cloud and supplies services to recipients in South Africa regularly. In instances like these, in the absence of clear and definitive place-of-supply rules, it is difficult to ascribe the transactions to a specific jurisdiction, and to tax them (for VAT purposes) accordingly.

However, in South Africa, in the context of "electronic services", a foreign supplier of electronic services is deemed to conduct an enterprise in the Republic if it satisfies any two of the following three requirements:

i) the recipient of the services is resident in South Africa;

ii) the payment for the electronic services originates from a bank in South Africa; and

iii) the recipient has a business, postal or residential address in South Africa. ${ }^{73}$

The term "resident" is defined in the VAT Act as "a resident as defined in the Income Tax Act 58 of 1962" (Income Tax Act). ${ }^{74}$ An extensive discussion of the term "resident" is not necessary for the purposes of this article. However, it suffices to say that residency in respect of natural persons consists of two tests: the ordinary resident test and the physical presence test. ${ }^{75}$ In respect of persons other than natural persons, a person is resident if it is

72 Paragraph $(b)(v i)$ of $\mathrm{s} 1$ of the definition of "enterprise" of the VAT Act; also see Van Zyl "The Collection of Value Added Tax on Cross-Border Digital Trade - Part 1: Registration of Foreign Vendors" 201447 Comparative International Law Journal of Southern Africa 154 157-161; De Swardt and Oberholzer "Digitised Products: How Compliant is South African Value Added Tax Act?" 200614 Meditari Accountancy Research 15 20-21.

73 Paragraph (b)(vi)(aa), (bb) and (cc) of $\mathrm{s} 1$ of the definition of "enterprise" of the VAT Act.

$74 \mathrm{~S} 1$ of the definition of "resident" in the VAT Act.

75 A resident is a person who ordinarily resides in the Republic of South Africa. Unfortunately, the Income Tax Act does not define the term "ordinarily resident". Hence, whether a person is resident in South Africa is a matter of fact. A person will be deemed to be ordinarily resident in South Africa if they call their natural abode as their real home or alternatively, a person's usual or physical residence. The physical presence test applies if a person is not ordinarily resident in South Africa. In terms of the physical presence test, a person will be deemed to be resident in South Africa if they are physically present in South Africa for periods:

-exceeding 91 days in aggregate during the current year of assessment; and -exceeding 91 days in aggregate during each of the five years of assessment preceding the current year of assessment; and

-exceeding 915 days in aggregate during the five years of assessment preceding the current year of assessment. 
incorporated, established, or formed in the Republic, or has its place of effective management in the Republic. ${ }^{76}$

The VAT Act does not state who is liable to establish the residency of the recipient of "electronic services". From the wording of the VAT Act, it appears that the onus is on the foreign supplier of "electronic services" to determine the recipient's residency. ${ }^{77}$ Establishing a recipient's residency creates an unnecessary administrative burden on foreign suppliers of "electronic services". ${ }^{78}$ The OECD recommends that the tax rules be clear and simple to understand so that taxpayers can anticipate the tax consequences in advance of a transaction, including knowing when, where and how the tax is to be accounted. ${ }^{79}$ The authors argue that this additional duty - the duty to determine the residency status of the recipient - adds to the existing complexity of the South African VAT system, and that it does not comply with the Ottawa agreement and the OECD recommendations.

The residence of a consumer of "electronic services", and payment originating from a South African bank, apply as proxies to establish the place of supply for "electronic services". ${ }^{80}$ However, it remains to be seen if these proxies prove to be sufficient in accurately establishing the identity of a consumer of "electronic services" in South Africa. ${ }^{81}$ It is also not clear what efforts the supplier must go to to determine the residency status of a recipient or the origin of a payment. What happens if the supplier fails to identify that the recipient is in South Africa, that payment originates from a South African bank, or that the recipient is resident in South Africa to the satisfaction of the Commissioner? ${ }^{82}$ The authors posit that the normal noncompliance or understatement penalties and interest as provided for in the Tax Administration Act (TAA) ${ }^{83}$ may apply. This can have a huge financial impact on foreign suppliers and may also lead to reputational damage. It is submitted that where a foreign supplier has verified that the customer has provided consistent information with a valid credit card, billing address, and IP address, all indicating the same address as residence, the supplier must be deemed to have discharged itself of the duty to determine the location of the recipient. Similarly, where the supplier has verified that the customer has provided consistent information indicating that payment originates from a South African bank, the supplier must be deemed to have discharged itself of the duty to locate the origin of the payment. At the time of writing, the SARS FAQ did not provide any guidelines on how and to what extent the

76 Par (b) of the definition of "resident" in s 1 of the Income Tax Act 58 of 1962.

$77 \mathrm{~S} 7(1)(c)$ of the VAT Act read with s 7(2) along with paragraph $(b)(v i)$ of $\mathrm{s} 1$ of the definition of "enterprise".

78 See in general the concerns raised in Van Zyl 2014 Comparative International Law Journal of Southern Africa 168-171, 175-183.

79 OECD Committee on Fiscal Affairs Electronic Commerce: Taxation Framework Conditions 4.

80 National Treasury Explanatory Memorandum on the Taxation Laws Amendment Bill 2013.

81 If the identity of the consumer is known, then, by implication, the place of consumption can be established.

82 See, for e.g., the concerns raised by Harmse "Value-Added Tax Consequences for Foreign Suppliers of Electronic Services into South Africa" 20153 World Journal of VAT/GST Law 115117.

83 See Ch 15 of the Tax Administration Act 28 of 2011. A complete discussion of the penalties falls outside the scope of this article. 
supplier must verify residency, establishment, or the origin of payment for purposes of raising South African VAT.

\section{Locating the place of supply in Australia}

In terms of Australian law, a foreign online business supplying digital goods to Australian consumers is required to charge an additional 10 per cent on the value of every transaction. ${ }^{84}$ An Australian consumer is defined as an Australian resident who is not registered for Australian GST purposes. ${ }^{85}$

As explained below, whether or not a consumer is an Australian resident for purposes of the Australian GST is a question of fact. However, the onus to establish whether a consumer is an Australian resident rests solely on the foreign supplier of digital goods.

In order to establish that a recipient of digital goods is an Australian customer, an online business should form a reasonable basis to believe that a recipient is in fact an Australian consumer. ${ }^{86}$ The basis upon which the online business relies consists of the typical systems and processes that a business uses in day-to-day operations. ${ }^{87}$

The following indicators are used to determine whether a recipient is an Australian consumer:

- $\quad$ the recipient's billing address;

- $\quad$ the recipient's mailing address;

- the recipient's banking or credit card details, including the location of the bank or the credit card;

- location-related data from third-party payment intermediaries;

- mobile phone SIM or landline country code;

- the recipient's country selection;

- IP address;

- geolocation software;

- the place of establishment of the recipient;

- representations and warranties given by the recipient;

- the origin of the correspondence; and

- locations, such as a $\mathrm{Wi}-\mathrm{Fi}$ spot, where the physical presence of the person receiving the service at that location is needed. ${ }^{88}$

Foreign suppliers of digital goods have a duty to employ all pertinent information that is available on the day of the transaction, including personal information provided by the recipient, to enable them to decide whether or not a recipient is an Australian resident. ${ }^{89}$ If the foreign supplier is still unable to decide on a recipient's residency, then the foreign supplier must weigh the

84 S 9-25(5)(d) of the Australian GST Act.

85 S 9-25(7) of the Australian GST Act.

86 S 84-100(2)(a) of the Australian GST Act.

87 Australian Goods and Services Tax Ruling 2017/1.

$88 \mathrm{Ibid}$. According to the Australian government, the list of indicators pointing to a recipient's residency is not closed.

89 lbid. 
information it has at its disposal in order to formulate the residency of the recipient. ${ }^{90}$ However, foreign online businesses are not required to attain extra information from the Australian consumer. ${ }^{91}$

Alternatively, a foreign online business may take reasonable steps to obtain information that will show whether a recipient is an Australian consumer. ${ }^{92}$ It follows that the steps taken by an online business are objective and every case should be judged on its own merits. ${ }^{93}$ It is recommended that SARS develop guidelines similar to those mentioned above to alleviate the administrative burden on foreign suppliers. Furthermore, foreign suppliers following the guidelines in good faith must be exempted from non-compliance or understatement penalties.

\section{Locating the place of supply in the EU}

In the EU, the location of the customer recipient of electronically supplied services is established by using what the EU describes as "presumptions". The presumptions are provided for as follows:

1. "Where a supplier of telecommunications, broadcasting or electronically supplied services provides those services at a location such as a telephone box, a telephone kiosk, a wi-fi hotspot, an internet café, a restaurant or a hotel lobby where the physical presence of the recipient of the service at that location is needed for the service to be provided to him by that supplier, it shall be presumed that the customer is established, has his permanent address or usually resides at the place of that location and that location and that service is effectively used and enjoyed there." 94

2. "If the location referred to above is on board a ship, aircraft or train carrying out a passenger transport operation effected within the community the country of the location shall be the country of departure of the passenger transport operation." 95

The above two presumptions are deemed to be "irrebuttable" for the purposes of locating the customer recipient of electronically supplied services. ${ }^{96}$ The "rebuttable" presumptions for the location of a customer provide that

"where telecommunications, broadcasting or electronically supplied services are supplied to a non-taxable person:

(a) through his fixed land-line, it shall be presumed that the customer is established, has his permanent address or usually resides at the place of installation of the fixed land-line;

(b) through mobile networks, it shall be presumed that the place where the customer is established, has his permanent address or usually resides is

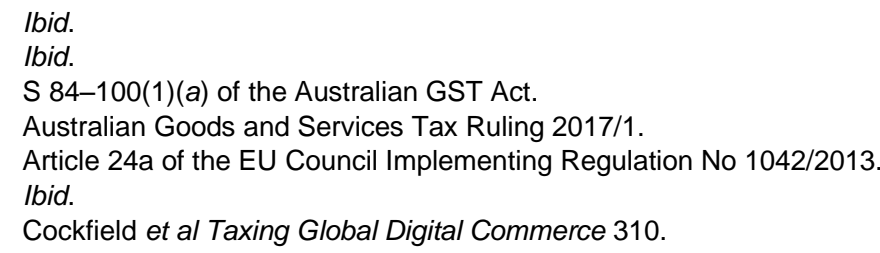


the country identified by the mobile country code of the SIM card used when receiving those services;

(c) for which the use of a decoder or similar device or a viewing card is needed and a fixed land line is not used, it shall be presumed that the customer is established, has his permanent address or usually resides at the place where the decoder or similar device is located or if that place is not known, at the place to which the viewing card is sent with a view to being used there; and

(d) under circumstances other than those referred to in Article 24a and the points above, it should be presumed that the customer is established, has his permanent address or usually resides at the place identified as such by the supplier on the basis of two items of non-contradictory evidence as listed in Article $24 \mathrm{f}$ of the Regulation." 97

The evidentiary information used to identify the location of the recipient of electronically supplied services includes the customer's billing address; the customer's bank address; the customer's IP address; the customer's fixed landline through which the service is supplied; the mobile country code (MCC) of the international mobile subscriber identity (IMSI) stored on the subscriber identity module (SIM) card used by the customer, and any other commercially relevant information. ${ }^{98}$

\section{Simplified registration of foreign vendors}

\section{The simplified VAT registration of foreign suppliers of electronic services in South Africa}

SARS has adopted a streamlined registration for foreign suppliers of "electronic services". What follows is a summary of this process to highlight its simplicity. Once the required threshold of taxable supplies has been met, ${ }^{99}$ a foreign supplier of electronic services must register for VAT on the SARS website and download a copy of the VAT 101 form. After completing and signing the VAT 101 form, it must be emailed together with supporting documents to SARS at eCommerceRegistration@sars.gov.za. ${ }^{100}$ The supplier will be notified within 24 hours of the outcome of registration. Similarly, deregistration can be effected by sending supporting documents to the same email address. Unlike domestic suppliers, the foreign supplier is not required to open a South African bank account, and it is not required to have a physical address in South Africa. This simplified registration process complies with the recommendations of the OECD. ${ }^{101}$ As supplier existence cannot be verified, the number of fake vendor registrations may increase. Such vendors may submit fake invoices in order to benefit from the input VAT regime. Even where these vendors submit tax compliance certificates

97 Article 24b of the EU Council Implementing Regulation No 1042/2013.

98 Article 24e and Article 24f of the EU Council Implementing Regulation No 1042/2013.

99 The current threshold is R50 000 per annum. From 1 April 2019, the threshold is R1 million per annum.

100 SARS "VAT Registration Guide for Foreign Suppliers of Electronic Services" http://www.sars.gov.za/AllDocs/OpsDocs/Guides/VAT-REG-01-G02\%20-

$\% 20$ VAT\%20Registration\%20Guide\%20for\%20Foreign\%20Suppliers\%20of\%20Electronic \%20Services\%20-\%20External\%20Guide.pdf (accessed 2018-04-01).

101 OECD http://dx.doi.org/10.1787/ 9789264271401-en 68-78. 
issued by the revenue authority of the country where they are established, there is no guarantee that the vendors actually conduct trade in South Africa, which is required for them to benefit from the input VAT regime. It must be noted that input VAT claims by a foreign registered vendor supplier of electronic services are limited to expenditure incurred in South Africa. To prevent fake vendor registration, it is recommended that input VAT deductions should not exceed any output VAT liability. Where the inputs exceed outputs, an input credit must be rolled over until the next reporting period. No pay-out of input VAT credits to foreign vendors should be executed. Of course, such a strict regime may prevent prospective legitimate vendors from registering and it may distort the market.

Once registered, a foreign supplier of electronic services is required to issue a tax invoice to a recipient within 21 days of the date of supply. ${ }^{102}$ The invoice must contain the following particulars: ${ }^{103}$

- the name and VAT registration number of the electronic services supplier;

- the name and address of the electronic services recipient;

- an individual serialised number;

- the date of issue;

- a description of the electronic services supplied;

- the consideration in money for the supply in the currency of any country (If the consideration is reflected in the currency of-

- the Republic of South Africa, the amount of the VAT charged or a statement that it includes a charge for the VAT and the rate at which the VAT was charged; or

- any country other than the Republic, the amount of the tax charged in the currency of the Republic or a separate document issued by the electronic services supplier to the electronic services recipient reflecting the amount of the tax charged in the currency of the Republic.); and

- the exchange rate used. 104

It follows that the foreign supplier of "electronic services" will account for and remit VAT to SARS and that the reverse-charge mechanism remains as backdrop. ${ }^{105}$ However, when the recipient imports "electronic services" from a non-registered foreign supplier of "electronic services", the burden to account for VAT shifts to that recipient. ${ }^{106}$

\footnotetext{
$22 \mathrm{~S} 20$ of the VAT Act.

$103 \mathrm{~S} 20(5 \mathrm{~B})$ of the VAT Act.

104 SARS "Binding General Ruling 28 Issue 1-2: Electronic Services" http://www.sars.gov.za/AllDocs/LegalDoclib/Rulings/LAPD-IntR-R-BGR-2015-03\%20\%20BGR28\%20Electronic\%20Services.pdf (accessed 2017-03-31).

105 Louw and Botha "Value-Added Tax on Electronic Services Supplied by Person Outside South Africa" http://www.thesait.org.za/news/168149/Value-added-Tax-on-electronicservices-supplied-by-persons-outside-South-Africa.htm (accessed 2017-04-05); Davis Tax Committee Second Interim Report on BEPS 9-10.

106 This is no different from the importation of services.
} 
Currently, there are no provisions in the VAT Act that enable SARS to monitor the compliance of foreign businesses. Moreover, there are currently no provisions in place within the VAT Act that impose penalties on foreign suppliers of "electronic services" in the event of non-compliance. However, as stated above, the non-compliance penalties and interest as provided for in the TAA apply. Notably, the TAA does not grant the Commissioner extraterritorial power to collect outstanding taxes, penalties and interest. ${ }^{107}$ In the absence of multilateral treaties and information exchange treaties, extraterritorial enforcement remains challenging. ${ }^{108}$ In other words, while the TAA empowers the Commissioner to impose penalties where a foreign supplier fails to register as a VAT vendor, the Commissioner has no legal basis to enforce such penalties in the jurisdiction in which the foreign supplier is incorporated or from which it operates. However, Spamer and Moonsamy opine that reputational damage from bad publicity might render foreign suppliers of "electronic services" willing to comply with the VAT Act. ${ }^{109}$ Wellknown multinational corporations cannot afford to be associated with tax non-compliance. Another option is to disallow input VAT deductions in the hands of domestic VAT vendors who make use of non-compliant foreign vendors. Similarly, deductions for income tax purposes in respect of "electronic services" supplied by non-compliant foreign suppliers to domestic taxpayers may be denied. Of course, this requires extensive auditing and close cooperation between different departments in SARS.

As stated above, the reverse-charge mechanism applies as backdrop. Accordingly, where the foreign supplier of "electronic services" is registered for South African VAT, but fails to collect and remit VAT, the South African consumer of the "electronic services" by default becomes liable to selfassess the transaction and remit VAT. ${ }^{110}$ The authors' own experiment at the SARS office in Pretoria revealed that SARS officials are unaware of the reverse-charge mechanism, and they were unable to process the authors' VAT return.

\section{The administrative burden of VAT registration for foreign suppliers of electronic services}

Upon registration as a VAT vendor in South Africa, a foreign supplier must levy VAT at 15 per cent on the supply of electronic services. ${ }^{111}$ SARS issued

107 The definition of "international agreement" in s1 of the TAA, read together with s 3(3), alludes to international cooperation only in cases where a foreign jurisdiction requests SARS's cooperation. It does not provide SARS with powers to enforce a South African tax liability in a foreign jurisdiction. Such extra-territorial powers or right of exchange of information must be negotiated by way of multilateral and bilateral agreements.

108 Davis Tax Committee Second Interim Report on BEPS 12.

109 Spamer and Moonsamy "New VAT Regulations for Electronic Services Effective April 2019" (2018) Lexology https://www.bakermckenzie.com/en/insight/publications/2018/12/new-vatregulations-for-electronic (accessed 2018-12-05).

110 In terms of $s$ 14(1) of the VAT Act, the recipient importer of imported services (including electronic services) must within 30 days of the earlier of the payment of the services or issue of an invoice furnish the Commissioner with a VAT return and remit VAT on the transaction.

$111 \mathrm{~S} 7(1)(a)$ of the VAT Act. 
a Binding General Ruling for "electronic services" on 23 February 2016. In it, SARS states that a supplier of electronic services "may" advertise the price of its electronic services exclusive of VAT on condition that it has a statement on its website indicating that VAT will be levied on supplies of "electronic services" to "electronic services" recipients. ${ }^{112}$ This means that a supplier is not obliged to advertise the price of "electronic services" inclusive of VAT. However, the consumer must be made aware of the fact that South African VAT will be levied on the purchase price if South African VAT applies.

The OECD has made reference to the fact that the registration mechanism imposes an unnecessary compliance burden on foreign suppliers. ${ }^{113}$ This stems from foreign businesses transacting with consumers in multiple jurisdictions. ${ }^{114}$ It is the authors' view that a foreign business may have to register in each and every jurisdiction where it has customers. It is fair to assume that this is not a path many businesses will be willing to follow - considering the expense and resources that may be incurred in facilitating registration in different states situated on as many as six different continents. ${ }^{115}$

It has also been stated that the registration mechanism poses an administrative burden on foreign suppliers of electronic services. ${ }^{116} \mathrm{~A}$ foreign business that registers in a foreign state must comply with that foreign state's laws. This can entail familiarising themselves with laws that they possibly do not understand. While it can be argued that these duties form part and parcel of doing business, many smaller businesses simply do not have the capacity to familiarise themselves and comply with difficult foreign law. Not only will they have to monitor online transactions, but foreign businesses must also keep records of all the transactions in instances where foreign law requires them to do so. As such, they are potentially prevented from trading internationally, which may lead to market distortions. While the concessions made by SARS to streamline the VAT registration of foreign suppliers of electronic services comply with the OECD guidelines, the Davis Tax Committee recommends that the registration process be closely monitored and reviewed on a regular basis to ensure that it remains compliant with the OECD simple registration guidelines. ${ }^{117}$ Despite the simplified registration process, many foreign suppliers are still unaware of their obligations in terms of the Act. ${ }^{118}$

112 SARS "Binding General Ruling (VAT): No. 28 (Issue 2)" (23 February 2016) https://www.sars.gov.za/wp-content/uploads/Legal/Rulings/BGR/LAPD-IntR-R-BGR-201503-BGR28-Electronic-Services.pdf (accessed 2021-09-01).

113 OECD Technical Advisory Group "Report by the Technology Technical Advisory Group" (2000) http://www.oecd.org/tax/consumption/1923248.pdf (accessed 2017-03-08).

114 Ibid.

115 Asia, Africa, Europe, South America, North America and Oceania.

116 Van Zyl 2014 Comparative International Law Journal of Southern Africa 168-171; Steyn 2010 SA Merc LJ 241-255; Steyn 2010 SA Merc LJ 241-255; OECD Consumption Tax Advisory Group "Consumption Tax Aspect of Electronic Commerce" (2000) http://www.oecd.org/tax/consumption/1923240.pdf (accessed 2017-06-15).

117 Davis Tax Committee Second Interim Report on BEPS 10.

118 Ibid. 


\section{The simplified VAT registration of foreign suppliers of digital goods in Australia}

Foreign suppliers of digital goods are required to register for purposes of GST if they carry on an enterprise within the Indirect Tax Zone (ITZ) ${ }^{119}$ and have an annual threshold turnover that exceeds $\$ 75000 .^{120} \mathrm{~A}$ foreign supplier is then required to collect the GST and remit it to the Australian Tax Office (ATO). ${ }^{121}$ Businesses may choose between two different registration systems - namely, the limited registration and the standard full registration.

The limited registration system is done online and allows foreign businesses to remit tax to the ATO expeditiously. In terms of this registration method, registration for foreign online businesses is simplified in the following manner:

- The online business is not required to establish its identity.

- Registration will be facilitated online.

- An ATO reference number (ARN) is issued instead of an Australian Business Number (ABN).

- The online business is not entitled to any GST credits.

- The online business must lodge GST returns and pay GST quarterly.

- The online business cannot issue tax invoices. ${ }^{122}$

In terms of the standard registration system, an online foreign business must apply for an ABN number. This number will enable identification to a foreign business on the ATO system. ${ }^{123}$ An ABN number is obtained after supplying the ATO with evidentiary documentation for the purposes of identification. ${ }^{124}$ The downside of this system is that the registration process may be tedious for foreign online businesses. ${ }^{125}$

119 The ITZ refers to Australia excluding other territories that fall outside the ambit of the GST.

20 S 23-5 read with s 23-15 of the Australian GST Act.

121 The Parliament of the Commonwealth of Australia "Explanatory Memorandum to the Tax and Superannuation Laws Amendment Bill of 2016" http://parlinfo.aph.gov.au/parllnfo/download/legislation/ems/r5613_ems_80fe4701-d4594971-9100-126d942757f1/upload_pdf/504670.pdf;fileType=application\%2Fpdf (accessed 2017-08-31).

122 Australian Taxation Office "Australian GST Registration for Non-Residents" https://www.ato.gov.au/Business/International-tax-for-business/In-detail/Doing-business-inAustralia/Australian-GST-registration-for-non-residents/ (accessed 2017-09-07); The Parliament of the Commonwealth of Australia "Explanatory Memorandum to the Tax and Superannuation Laws Amendment Bill of 2016" http://parlinfo.aph.gov.au/parllnfo/ download/legislation/ems/r5613_ems_80fe4701-d459-4971-9100-

126d942757f1/upload_pdf/504670.pdf;fileType=application\%2Fpdf (accessed 2017-08-31) PWC Australia "Changes to Australian GST for Cross-Border Supplies Commencing 1 July 2017: Are You Ready?" (2017) TaxTalk http://ebiz.pwc.com/wpcontent/uploads/2017/06/australia-gst-changes-13jun17.pdf (accessed 2017-09-07).

123 Australian Taxation Office https://www.ato.gov.au/Business/International-tax-forbusiness/In-detail/Doing-business-in-Australia/Australian-GST-registration-for-nonresidents/.

124 Ibid.

125 Ibid. 
The registration system is beneficial to Australian consumer recipients as their compliance burden will be all but insignificant. ${ }^{126}$

\section{The simplified VAT registration of foreign suppliers of electronic supplied services in the European Union}

A foreign supplier that provides electronically supplied services can register and account for VAT in the jurisdiction of the identified customer if the online business does not have a permanent establishment in that jurisdiction. ${ }^{127}$ This mechanism, known as the Mini One Stop Shop (MOSS), is optional; online businesses are not compelled to use it. MOSS is available to online businesses situated inside and outside the EU. ${ }^{128}$

Upon registration in an EU state, an online business declares the transaction to the relevant tax authorities and pays the VAT due by means of a web portal in the state where the identity of the customer has been established. ${ }^{129}$

An online business that has a fixed or permanent establishment in the EU may not use MOSS to collect VAT for the supplies made in another EU state in which it has a permanent establishment. ${ }^{130}$ The EU VAT directive does not define the term "permanent establishment". The definition can, however, be found in the implementing regulation. A permanent or fixed establishment is an "establishment that is characterised by a sufficient degree of permanence and a suitable structure in terms of human and technical resources to enable it to receive and use the services supplied to it for its own needs". ${ }^{131}$

An EU online business that uses MOSS must register in the EU state where it has identified the consumer. ${ }^{132}$ When the online company registers for VAT purposes, it is issued with a VAT identification number. A VAT identification number is also issued to a non-EU online company that supplies services to an EU state where the consumer has been identified. ${ }^{133}$

It appears that having some sort of permanent establishment is a prerequisite to use MOSS. The requirement of a fixed or permanent establishment could stem from the necessity to establish the identity of the

126 The Parliament of the Commonwealth of Australia "Explanatory Memorandum to the Tax and Superannuation Laws Amendment Bill of 2016" http://parlinfo.aph.gov.au/parllnfo/ download/legislation/ems/r5613_ems_80fe4701-d459-4971-9100-126d942757f1/ upload pdf/504670.pdf;fileType=application\%2Fpdf (accessed 2017-08-31).

127 European Commission "Guide to the VAT Mini One Stop Shop" (2013) http://ec.europa.eu/taxation customs/sites/taxation/files/resources/documents/taxation/vat/h ow_vat_works/telecom/one-stop-shop-guidelines_en.pdf (accessed 2017-07-01).

128 Ibid.

129 Dale and Vincent "The European Union's Approach to VAT and e-Commerce" 20176 World Journal of VAT/GST Law 55-61.

130 European Commission http://ec.europa.eu/taxation customs/sites/taxation/files/resources/ documents/taxation/vat/how_vat_works/telecom/one-stop-shop-guidelines_en.pdf.

131 Article 11 of the EU Council Implementing Regulation No 282/2011.

132 European Commission http://ec.europa.eu/taxation_customs/sites/taxation/files/resources/ documents/taxation/vat/how vat works/telecom/one-stop-shop-guidelines en.pdf.

133 Ibid. 
business and the place of taxation for the supply of electronically supplied services. This can be a hurdle for businesses operating in the cloud. Mikutiené states that the fixed establishment concept can be used to determine the place of supply for B2B as well as B2C transactions. ${ }^{134}$ According to Mikutiené, the fixed establishment concept "strongly influences the entitlement of the Member States to tax supplies and affects the cash flow of both the Member States and the businesses supplying and acquiring cross-border services". 135

\section{MOSS: Successes, challenges and further improvements}

The European Commission states that the implementation of MOSS has been largely successful. According to its findings, ${ }^{136}$ an amount of $€ 3$ billion of VAT was paid and collected in the year 2015. During that same period, 12000 businesses made use of the MOSS system. Furthermore, the use of MOSS has led to the reduction of costs for businesses of $€ 500$ million. MOSS also covered 70 per cent of EU turnover on electronic services. Overall, businesses were satisfied with the implementation of MOSS and revenue collection rose significantly as a result. ${ }^{137}$

According to the European Commission, one of the main challenges when using MOSS is the compliance costs that businesses face when transacting in different states. ${ }^{138}$ Online businesses have to deal with as many as 28 different states when transacting with customers in the EU. Moreover, with the EU having 24 official languages, it seems almost impossible for online businesses to familiarise themselves with each and every language when dealing with the EU states.

Online businesses have identified market distortions as another impediment. ${ }^{139}$ An online business transacting with EU states will encounter different VAT rates that could apply to the same type of electronic services. For instance, a supply of computer software will be subject to VAT at 24 per cent in Italy and 19 per cent in Germany. These market distortions could lead to little or no taxation of that electronic service in certain countries. ${ }^{140}$

Interacting with customers in different states translates into an engagement with different legal frameworks. ${ }^{141}$ An online business transacting in the EU will encounter multiple sets of legal rules relating to

\footnotetext{
134 Mikutiené "The Preferred Treatment of the Fixed Establishment in European VAT" 20143 World Journal of VAT/GST Law 166166.

135 Ibid.

136 European Commission "Modernising VAT for Cross-Border B2C e-Commerce" (2016) https://ec.europa.eu/taxation_customs/sites/taxation/files/swd_2016_379.pdf (accessed 2017-07-05).

137 Ibid.

138 Ibid.

139 Ibid.

140 Ibid.

141 Ecommerce Europe "Analysis of the Survey Barriers to Growth" https://www.ecommerce-europe.eu/app/uploads/2016/07/survey-barriers-to-growthecommerce-europe-2015-1.pdf (accessed 2017-07-05). 
things such as the law of contract, privacy and data protection. ${ }^{142}$ These rules are set out differently in each EU state. Becoming familiar with and complying with these separate rules could prove to be burdensome for an online business.

Krinis $^{143}$ argues that MOSS poses additional challenges for online businesses. These include difficulties with the identification of customers, record-keeping and home country audits. In terms of record-keeping requirements, an online business is required to keep records for a period of 10 years. ${ }^{144}$ Krinis states that the time frame for record-keeping should be reduced. ${ }^{145}$ Krinis also states that home country audits should be introduced for online businesses in the state where the customer has been identified. ${ }^{146}$ Moreover, Krinis recommends that only two items of evidence ${ }^{147}$ be used to establish the identity of a customer. ${ }^{148}$

Along with these improvements suggested by Krinis, the European Commission has also highlighted other enhancements that can be applied to MOSS. First, the European Commission agrees with Krinis and has acknowledged that the 10-year record-keeping period is lengthy and that other avenues should be explored. ${ }^{149}$ Secondly, better communication is required between micro-businesses, member states and the European Commission. ${ }^{150}$ Thirdly, after micro-businesses stressed the lack of a threshold as a problematic area, the European Commission on 1 January 2019 introduced thresholds to the amount of $€ 10000^{151}$ and $€ 100000^{152}$ to

142 Ibid.

143 Krinis VAT Challenges of the Digital Economy: An EU Perspective (Master of Accounting dissertation, Universidade do Minho Portugal) 201666.

144 European Commission https://ec.europa.eu/taxation_customs/sites/taxation/files/swd_2016 379.pdf.

145 Krinis VAT Challenges of the Digital Economy 67.

146 Krinis VAT Challenges of the Digital Economy 85.

147 Krinis VAT Challenges of the Digital Economy 85.

148 Krinis VAT Challenges of the Digital Economy 69-70.

149 European Commission https://ec.europa.eu/taxation_customs/sites/taxation/files/swd_2016 _379.pdf.

150 Ibid.

151 An annual $€ 10000$ turnover threshold is introduced from 1 January 2019, up to which threshold the place of supply of relevant supplies of cross-border telecommunication, broadcasting, and electronically supplied services (TBE services) remains in the member state where the supplier is established, has his permanent address or usually resides. The application of this threshold is subject to the following conditions: a) the supplier is established, has his permanent address or usually resides in only one member state; b) he supplies TBE services to customers who are established, have their permanent address or usually reside in another member state; c) the total value of TBE services supplied to other member states does not exceed $€ 10000$ (exclusive of VAT) in the current and in the preceding calendar year.

152 A threshold applies of $€ 100000$ up to which one piece of evidence is sufficient to determine the place of supply. The application of this threshold is subject to the following conditions: 1) the total value (exclusive of VAT) of TBE services provided by the supplier from his business establishment or a fixed establishment located in a member state to customers who are established, have their permanent address or usually reside in other member states does not exceed $€ 100000$ in the current and in the preceding calendar year; 2) the item of evidence is provided by a person involved in the supply of the services other than the supplier or the customer; 3 ) the item of evidence is listed in points (a) to (e) of Article $24 f$ of the VAT Implementing Regulation. As soon as the threshold is exceeded during a 
assist micro-businesses (SMEs). ${ }^{153}$ The thresholds apply to suppliers who are incorporated in an EU member state. For foreign suppliers of electronically supplied services, a threshold has not yet been implemented. Fourthly, identification of the customer remains a concern. ${ }^{154}$ As a way to simplify the identification of consumers, Veltrop suggests that a universal pricing system should be adopted to entice consumers to provide the correct personal details to suppliers. ${ }^{155}$ Veltrop also states that as a means to reduce compliance costs for suppliers, "fast and simple" ordering systems should be made accessible to consumers. ${ }^{156}$ In addition, a supplier is not protected in a case of discrepancies where inaccurate information is obtained bona fide. ${ }^{157}$ However, where the supplier has verified that the customer has provided consistent information with a valid credit card, billing address, and IP address, all indicating the same residence, it can be said that the supplier has acquitted itself of the duty to determine the customer's location. ${ }^{158}$

Other commentators have underlined the need for the harmonisation of EU VAT rules in order to reduce the compliance burden on suppliers. ${ }^{159}$

The implementation of MOSS has obviously not been plain sailing. Although it has helped tax authorities to collect an increased amount of VAT, MOSS has given rise to a set of challenges. Among those challenges faced by online businesses is the unenviable task of dealing with 24 different languages, 28 different legal frameworks and, potentially, audits from 28 different states. There is a need for the relevant rules, policies and legal frameworks to be harmonised to stem the trend of under-taxation.

The European Commission is in the process of improving MOSS. These improvements will be implemented over an extended period of time. Since the EU is the recognised forerunner in the implementation and use of MOSS, ${ }^{160}$ perhaps members of regional African trade organisations ${ }^{161}$ will

calendar year, the normal rules apply, meaning that again two pieces of evidence are required.

153 Dale and Vincent 2017 World Journal of VAT/GST Law 56.

154 European Commission https://ec.europa.eu/taxation_customs/sites/taxation/files/swd 2016_379.pdf; Merkx "Fixed Establishments and VAT Liabilities Under EU VAT: Between Illusion and Reality" 201223 International VAT Monitor 2222.

155 Veltrop "How to Identify Customers of e-Services in VAT" 20141 Taxation Perspectives 121 137.

156 lbid.

157 Fitzgerald "US Companies' Sales to EU Consumers Subject to VAT on Digital Downloads" 2002 The Tax Adviser 382.

158 European Parliament: Directorate-General for Internal Policies Simplifying and Modernising in the Digital Single Market (2012) European Parliament 61.

159 Vazquez, Duncan and Phillipe "The European Mini One-Stop Shop: A Model for Future Indirect Tax Compliance?" (2017) The Tax Adviser http://www.thetaxadviser.com/issues/ 2017/jun/european-mini-one-stop-shop-indirect-tax-compliance.html (accessed 2018-07-4); Lamensch "Are the 'Reverse-Charging' and the 'One-Stop-Scheme' Efficient Ways to Collect VAT on Digital Supplies?" 20121 World Journal of VAT/GST Law 1 3; Parrilli "Electronically Supplied Services and the Value Added Tax: The European Perspective" 200914 Journal of Internet Banking and Commerce 1 14-17; Minor "A Primer on the "OneStop-Shop' VAT Compliance Scheme for Non-EU Suppliers of e-Commerce Services" 2011 13 Tax Notes International 10431045.

160 European Commission https://ec.europa.eu/taxation_customs/sites/taxation/files/swd 2016_379.pdf. 
follow suit in adopting mechanisms that are similar to MOSS. The implementation of MOSS has brought about a shift in the way VAT is collected in the EU. Albeit not flawless, MOSS, or a mechanism akin to MOSS may be employed in the Southern African Development Community (SADC). Its implementation in the SADC ${ }^{162}$ region would enable foreign suppliers of digital goods to register for and account for VAT in one country in the SADC region instead of registering in each country in SADC. A model similar to that of MOSS will not be easy to implement without examining MOSS in its current form; improving on it where the need arises; harmonising VAT rules in the SADC region; ${ }^{163}$ greater cooperation between member states; and expanding the tax administration, among other things.

\section{Other new developments in South Africa: VAT vendor registration of platforms}

In 2016, SARS published a draft Binding General Ruling on Electronic Services Supplied via Intermediaries (the Ruling). ${ }^{164}$ In terms of the Ruling, foreign suppliers of electronic services would not be required to register or account for VAT in South Africa, subject to the following provisos: ${ }^{165}$

“(a) [The foreign supplier] only supplies electronic services via an intermediary's platform;

(b) The intermediary is a registered vendor in the Republic;

(c) The electronic services supplier and the relevant intermediary enter into a written agreement confirming that the intermediary will-

(i) account for VAT on the supply of the electronic services supplied via its platform;

(ii) be liable for the payment of VAT in respect of the supply of said electronic services;

(d) The intermediary will retain accounting records, as envisaged in section 29 of the Tax Administration Act 28 of $2011^{166}$ for the supply of electronic

161 Southern African Development Community (SADC) of which South Africa is a member; Economic Community of West African States (ECOWAS); Common Market for East and Southern Africa (COMESA).

162 Currently consisting of Angola, Botswana, Malawi, Lesotho, Namibia, Zimbabwe, Swaziland, Democratic Republic of Congo, Mozambique, Zambia, Madagascar, Tanzania, South Africa, Seychelles and Mauritius.

163 In 2016, the SADC Secretariat published Guidelines for Co-Operation in Value Added Taxes in the SADC Region, the main aim of which is to harmonise the VAT rules in the SADC region. However, these guidelines cannot be construed to reflect the policy or laws of any of the SADC member countries.

164 SARS "Draft Binding General Ruling on Electronic Services Supplied via Intermediaries" https://www.sars.gov.za/wp-content/uploads/Legal/Drafts/LAPD-LPrep-Draft-2016-22-DraftBGR-on-electronic-services-supplied-via-intermediaries.pdf (accessed 2017-04-09).

165 Visser "Tax Practitioners Favour Move to Simplify VAT Rules for Foreign e-Commerce" (2016) http://www.thesait.org.za/news/287478/Tax-practitioners-favour-move-to-simplifyVAT-rules-for-foreign-e-commerce-.htm (accessed 2017-04-09); SARS http://www.sars.gov.za/AllDocs/LegalDoclib/Drafts/LAPD-LPrep-Draft-2016-22\%20\%20Draft\%20BGR\%20on\%20electronic\%20services\%20supplied\%20via\%20intermediaries .pdf.

166 S 29 of the TAA states: "(1) A person must keep the records, books of account or documents that $(a)$ enable the person to observe the requirements of a tax Act; $(b)$ are specifically required under a tax Act or by the Commissioner by public notice; $(c)$ enable SARS to be satisfied that the person has observed those requirements. (2) The 
services by the electronic services supplier falling within this arrangement; and

(e) The intermediary, by entering into this arrangement accepts that it is liable for any outstanding taxes of the electronic services supplier in respect of the supply of the said electronic services as made via an intermediary's platform." 167

In terms of the Ruling, a foreign supplier of electronic services will not be required to register for VAT if the intermediary is already registered for VAT and the foreign supplier has entered into an agreement with the intermediary wherein the latter will account for and pay the VAT to SARS. ${ }^{168}$

It follows that if a foreign supplier does not supply electronic services via an intermediary's platform, the former will still be required to register and account for VAT where the taxable supplies at the end of any year exceed R1 million. ${ }^{169}$

The Ruling defines an "intermediary" as a person who facilitates the supply of "electronic services" supplied by an "electronic services" supplier and that is responsible for, inter alia, issuing invoices and collecting payment for the supply. ${ }^{170}$

The South African Institute of Tax Practitioners (SAIT) said in its submissions to SARS that the Ruling allows South African intermediaries to assume responsibility for VAT in lieu of foreign suppliers of "electronic services". 171 SAIT also submitted that the Ruling is based on SARS's discretionary power in terms of section $72^{172}$ of the VAT Act. ${ }^{173}$ The use of

requirements of this Act to keep records, books of account or documents for a tax period apply to a person who (a) has submitted a return for the tax period; $(b)$ is required to submit a return for the tax period and has not submitted a return for the tax period; or $(c)$ is not required to submit a return but has, during the tax period, received income, has a capital gain or capital loss or engaged in any other activity that is subject to tax or would be subject to tax but for the application of a threshold or exemption. (3) Records, books of account or documents need not be retained by the person described in: (a) subsection (2)(a), after a period of five years from the date of the submission of the return; and $(b)$ subsection (2)(c), after a period of five years from the end of the relevant tax period."

167 SARS http://www.sars.gov.za/AllDocs/LegalDoclib/Drafts/LAPD-LPrep-Draft-2016-22\%20\%20Draft\%20BGR\%20on\%20electronic\%20services\%20supplied\%20via\%20 intermediaries.pdf.

168 Visser http://www.thesait.org.za/news/287478/Tax-practitioners-favour-move-to-simplifyVAT-rules-for-foreign-e-commerce-.htm.

169 Visser http://www.thesait.org.za/news/287478/Tax-practitioners-favour-move-to-simplifyVAT-rules-for-foreign-e-commerce-.htm; SARS http://www.sars.gov.za/AllDocs/LegalDoclib/ Drafts/LAPD-LPrep-Draft-2016-22\%20-\%20Draft\%20BGR\%20on\%20electronic\%20 services\%20supplied\%20via\%20intermediaries.pdf.

170 Ibid.

171 The SAIT letter to the South African Revenue Service in respect of the Draft Binding General Ruling Relating to Electronic Services Supplied by Intermediaries (VAT) dated 25 April 2016, [online] www.thesait.org.za/resource/resmgr/2016_Submissions/25_Apr_2016_SAIT_BGR Elect.pdf (accessed 2017-04-09).

172 S 72 of the VAT Act states: "If in any case the Commissioner is satisfied that in consequence of the manner in which any vendor or class of vendors conducts his, her or their business, trade or occupation, difficulties, anomalies or incongruities have arisen or may arise in regard to the application of any of the provisions of this Act, ... the Commissioner may make a decision as to $-(a)$ the manner in which such provisions shall be applied; or $(b)$ the calculation or payment of tax or the application of any rate of zero per cent or any exemption from tax provided in this Act, in the case of such vendor or class of 
an intermediary for the purposes of tax collection should not be underestimated. Ligthart argues that enabling intermediaries to collect VAT could potentially reduce compliance costs. ${ }^{174}$ This could be an important aspect for both foreign suppliers of "electronic services" and tax authorities. It would enable foreign suppliers to transact with customers with the knowledge that the administrative burden of tax collection has shifted to the intermediary. Hence, they would not incur unnecessary expenses when transacting online with customers. For tax authorities, the burden of tax collection and VAT liability would shift to a third party. Tax authorities' administrative costs would be significantly reduced. A tax authority's resources could then be channelled into other activities like consumer tax awareness campaigns, international cooperation and improving tax policies.

Section 8 of the Rates and Monetary Amounts and Amendment of Revenue Laws Act ${ }^{175}$ introduced into the definition of "enterprise" "the activities of an intermediary". An "intermediary" is defined as "a person who facilitates the supply of electronic services supplied by the electronic services supplier and who is responsible for issuing the invoices and collecting payment for the supply". 176 The effect of the amendment is that intermediaries or platforms that facilitate the supply of "electronic services" (on behalf of a foreign supplier), and who are responsible for invoicing and collecting payment, are required to register as VAT vendors in South Africa. The platform or intermediary is then deemed to be the supplier. The platform or intermediary, and not the actual supplier, is liable to collect and remit VAT. Although the amendment is in line with the OECD Working Party 9 (WP9) recommendations, ${ }^{177}$ some of the OECD recommendations were not incorporated. First, under the South African position (and counter to the OECD view), the digital platform or intermediary cannot apply for an exclusion where it cannot essentially fulfil the role of VAT-collecting vendor. ${ }^{178}$ Secondly, the OECD recommends that taxing point must be determined as the time at which confirmation of payment is received by or on behalf of the supplier. ${ }^{179}$ The authors posit that the general time-of-supply rules apply: where an intermediary is registered on the invoice basis, the earliest of issue of the invoice or receipt of payment will be deemed to be the time of supply; and where an intermediary is registered on the payment

vendors or any person transacting with such vendor or class of vendors as appears to overcome such difficulties, anomalies or incongruities: Provided that such decision or arrangement shall not have the effect of substantially reducing or increasing the ultimate liability for tax levied under this Act."

173 See SAIT letter to the South African Revenue Service in respect of the Draft Binding General Ruling Relating to Electronic Services Supplied by Intermediaries (VAT) dated 25 April 2016, [online] www.thesait.org.za/resource/resmgr/2016_Submissions/25_Apr_2016_SAIT BGR Elect.pdf (accessed 2017-04-09).

174 Ligthart "Consumption Taxation in a Digital World: A Primer" 2004102 CentER Discussion Paper 1 13-14.

17521 of 2018.

$176 \mathrm{~S} 8(1)(b)$ of the Rates and Monetary Amounts and Amendment of Revenue Laws Act 21 of 2018. See also s 1 of the definition of "intermediary" in the VAT Act.

177 See, in general, OECD "The Role of Digital Platforms in the Collection of VAT/GST on Online Sales" (2019) http://www.oecd.org/tax/consumption/the-role-of-digital-platforms-inthe-collection-of-vat-gst-on-online-sales.pdf (accessed 2020-01-08).

178 lbid.

179 Ibid. 
basis, the time at which confirmation of payment is received by or on behalf of the supplier applies will be the time of supply. Thirdly, the OECD recommends that the intermediary's VAT compliance liability must be limited to what is strictly necessary. ${ }^{180}$ The VAT Act is silent on the extent of the intermediary's liability where it has made reasonable efforts to secure the accuracy and reliability of the information received from the underlying supplier, and where it collects and remits VAT accordingly. In the absence of limited liability rules, the authors postulate that non-compliance and understatement penalties in terms of the TAA may apply. It is submitted that where an intermediary has verified that the underlying supplier has provided consistent information in respect of the value of the "electronic services", billing, place and time of supply, the intermediary must be deemed to have discharged itself of the duties imposed on it by the VAT Act.

\section{CONCLUSION}

Notably, Van Zyl and Schulze submit that the collection of VAT on the supply of digital goods by means of the registration mechanism is ineffective if there is no collaboration between existing states. ${ }^{181}$ In addition, the reverse-charge mechanism relies solely on the integrity of the recipient of imported services. There is a likelihood that a recipient of imported services will not account for VAT to SARS. This is because the taxpayer is either unaware of the duty to pay VAT or the taxpayer perceives tax collection to be an unnecessary burden and time consuming. SARS's reliance on a consumer's integrity to report the transaction places an unnecessary burden on the consumer. Such reliance on the consumer highlights the inadequacies of the reverse-charge mechanism to collect VAT on imported services. Moreover, SARS does not have a provision or mechanism available to enforce tax compliance on the reverse-charge mechanism other than the provisions in the TAA. In the authors' opinion, the value of the majority of individual transactions escaping the VAT net are too insignificant for SARS to audit individual consumers and raise additional tax and penalties. Collectively, however, these transactions may result in base erosion.

A recipient may easily dispose of digital services after consumption without SARS becoming aware of their existence. It then becomes difficult for SARS to establish or to prove that the services were imported and consumed. Furthermore, in order for SARS to prove that services were imported, the recipient's identity must be ascertained. At present, SARS is not able to do this because there are currently no measures in place in the VAT Act to facilitate the verification of a recipient of imported services on $\mathrm{B} 2 \mathrm{C}$ transactions. It may be concluded that the inability to verify an identity translates into an ineffective process to conduct an audit on the transaction. In addition to identifying the recipient, SARS must establish the type of service rendered. This can only be done where the place of consumption is known.

80 Ibid.

181 Van Zyl and Schulze "The Collection of Value Added Tax on Cross-Border Digital Trade Part 2: VAT Collection by Banks" 201447 Comparative International Law Journal of Southern Africa 316317. 
While the taxation of digital goods in Australia is still in its infancy, and although it is perceived that the Australian model is significantly based on the South African model, ${ }^{182}$ there are a lot of positives that may be garnered from the new laws. First, the registration procedure has been simplified to allow foreign suppliers of digital goods to register for Australian GST without much trouble. With the added incentive of having a choice between two types of registration system, foreign suppliers may well be encouraged to conduct business in Australia. Secondly, shifting the GST liability from supplier to the operator of an electronic distribution platform (EDP) should be welcomed by suppliers.

The indicators to identify a consumer recipient as applied in Australia are significantly more extensive than the proxies applied in terms of the South African VAT Act. On the one hand, an extensive list of indicators simplifies the identification task for the supplier; on the other, an extensive list could pose a strenuous burden on foreign suppliers. It would seem that the obligation to identify consumer recipients may not be sustainable in the long term as it constantly demands time and resources.

Throughout, the authors have argued that SARS has difficulty in ascertaining whether a supply of electronic services has occurred in South Africa. This is simply because there are presently no mechanisms in place in the VAT Act that will aid the fiscus to identify consumer recipients of digital goods. This problem is compounded by the fact that the current VAT Act does not have explicit place-of-supply rules.

Despite the introduction of proxies in the VAT Act, it seems that the burden is on the foreign suppliers of digital goods to ascertain the jurisdiction of the consumer recipient of digital goods. This is an unnecessary burden on the foreign suppliers of digital goods.

A lack of international cooperation and coordination regarding what constitutes "electronic services" has compounded the problem. The new Regulations broaden the scope of what constitutes electronic services. While the updated Regulations are long overdue, the authors stress that the overly broad definition allows for unintended double-taxation of transactions. Additional measures must be put in place to exempt a transaction from South African VAT where it is subject to VAT/GST in a foreign jurisdiction.

It remains difficult for a single state to apply the registration mechanism effectively without cooperation from other states. If other states are reluctant or unwilling to cooperate, then the efficacy of the registration mechanism becomes tenuous. The authors endorse the Davis Tax Committee recommendation that the option of payment or collection agents either acting as agents or third-party service providers - to be appointed as registered VAT vendors on behalf of foreign suppliers of electronically supplied services - must be considered. ${ }^{183}$

182 The similarities in the Australian and South African systems are indicated in this article. It is well known that the Australian legislator collaborated with the National Treasury of South Africa in developing the Australian GST rules on the taxation of e-commerce transactions.

183 Davis Tax Committee Second Interim Report on BEPS 11, 99-103. For a complete discussion of third-party collection agents, see Van Zyl and Schulze 2014 Comparative International Law Journal of Southern Africa 316-349. 
The new registration threshold is welcomed. In the authors' view, it removes the discrimination between foreign and local suppliers of ecommerce, and it will result in a more competitive e-commerce market.

With the growth of e-commerce comes the possibility of new technological advancements. These new technological advancements will bring about a new set of encounters for tax authorities. If tax authorities do not find ways to come to terms with the growth of e-commerce, the conclusion is that the taxes due will go uncollected. This becomes an obstacle, particularly in developing countries where there is an overreliance on VAT as a source of revenue for government expenditure. 